\title{
Penerapan Model Pembelajaran Project Based Learning Untuk Meningkatkan Motivasi Belajar Ekonomi Pada Siswa Kelas X Smk
}

\author{
*Iis Lesnowati ${ }^{1)}$, Hafifi ${ }^{2)}$ \\ Program Studi Pendidikan Ekonomi, Fakultas Ilmu Pendidikan, Universitas Panca Sakti Bekasi \\ Corresepondence author: iislesnowati895@gmail.com
}

DOI: https://doi.org/10.37012/ijpmht.v5i2.652

\begin{abstract}
ABSTRAK
Project Based Learning adalah sebagai pembelajaran yang menggunakan proyek. Tujuan penelitian ini untuk mengungkapkan model pembelajaran project based learning (X) meningkatkan motivasi belajar ekonomi (Y). Penelitian ini penelitian kuantitatif dengan pendekatan survei. Sampel penelitian menggunakan tenik random sampling. Jumlah sampel penelitian sebanyak 51 siswa. Pengambilan data menggunakan intrumen yang valid dan reliabel. Analisis menggunakan regresi sederhana, hasil penelitian ini mengungkapkan : (1) Persamaan Regresi Linear Y $=47,278+0,367$ X. (2) Model pembelajaran project based learning berpengaruh positif terhadap motivasi belajar ekonomi siswa kelas X SMK. (3) Uji Signifikansi persamaan garis regresi $F_{\text {hit }} 0,023>0,05$ dengan demikian regresi $Y$ atau $\mathrm{X}$ adalah signifikan atau penerapan model pembelajaran project based learning berpengaruh terhadap motivasi belajar ekonomi siswa. (4) Koefisien kolerasi (rxy) $=0,317$ dan $\mathrm{F}_{\text {hit }}\left(\mathrm{F}_{\text {change }}\right)=$ 5,471 , dengan $\mathrm{p}$-value $=0,023>0,05$. Dengan demikian keofisien kolerasi $\mathrm{X}$ dan $\mathrm{Y}$ yang berarti Signifikan.
\end{abstract}

Kata Kunci : Project Based Learning, Motivasi Belajar.

\begin{abstract}
The Project Based Learning is as learning that uses projects. The purpose of this study is to reveal the project-based learning model $(X)$ to increase motivation to learn economics $(Y)$. This research is a quantitative research with a survey approach. The research sample used random sampling technique. The number of research samples was 51 students. Data collection using valid and reliable instruments. Analysis using simple regression, the results of this study reveal: (1) Linear Regression Equation $Y=$ 47,278 + 0,367 X. (2) Project-based learning model has a positive effect on students' motivation to learn economics in class X SMK. (3) Significance test of the regression line equation Fhit $0.023>$ 0.05 so that the $Y$ or $X$ regression is significant or the application of the project based learning model has an effect on students' motivation to learn economics. (4) The correlation coefficient (rxy) $=0.317$ and Fhit $($ Fchange $)=5.471$, with $p$-value $=0.023>0.05$. Thus the correlation coefficient of $X$ and $Y$ which means Significant.
\end{abstract}

Keywords: Project Based Learning, Learning Motivation. 


\section{PENDAHULUAN}

Pendidikan berperan penting untuk mempersiapkan sumber daya manusia (SDM) yang berkualitas dalam pengetahuan, mempunyai keterampilan yang dibutuhkan untuk kelangsungan hidup dan menguasai teknologi untuk mengikuti perkembangan zaman yang niatnya akan lebih berguna untuk kemajuan kehidupan individu itu sendiri maupun kemajuan suatu bangsa. Pendidikan berfungsi mengembangkan kemampuan dan membentuk watak serta peradaban bangsa yang bermanfaat dalam rangka mencerdaskan kehidupan bangsa.

Kualitas sistem pendidikan di Indonesia khususnya pada sektor pendidikan formal SMA/ SMK harus segera dibenahi. Banyak faktor yang harus dibenahi diantaranya kurikulum, fasilitas, SDM guru, kerjasama dengan dunia industri/ lapangan pekerjaan, faktor birokrasi, kebudayaan dan sebagainya. Untuk mengurai banyak faktor tersebut, salah satu hal yang sederhana namun strategis yang harus dibenahi adalah cara mengajar guru. Cara atau metode mengajar guru dikatakan strategis karena berdampak langsung terhadap minat/ motivasi belajar siswa dan terhadap prestasi belajar (meningkatkan kulitas siswa/ lulusan). Peranan cara (metode, strategi, pendekatan, tehnik) mengajar guru sangat penting sebagai scalfolding (vasilitasi/ penunjang utama) dalam meningkatkan motivasi belajar dan efektifitas belajar. Menurut Vigotsky dalam teori Social Constructivism mengatakan bahwa pentingnya faktorfaktor social dalam belajar. Karena selama kegiatan belajar terdapat saling pengaruh antara bahasa dan tindakan dalam kondisi social. Dengan mengemukakan bahwa belajar itu harus berlangsung dalam kondisi social, terlihat betul bahwa dalam belajar konstruktif. Maka hal ini menjadi para peneliti konstruktif mereka di kenal dengan nama konstruktivis social.

Pendidikan dinyatakan berhasil apabila siswa mampu menerima dan memahami kegiatan pembelajaran. Untuk mencapai tujuan guru harus dapat menyampaikan materi yang menarik agar materi dapat dipahami dan dimengerti oleh siswa. Guru diharuskan mampu memberikan materi dengan metode yang menyenangkan hal ini dikarenakan cara mengajar guru masih tersandra oleh gaya tradisional yang lebih terpusat pada peran guru (teacher centered) guru terlalu dominan dalam proses pembelajaran sedangkan siswa sangat pasif. Seharusnya pembelajaran itu berpusat pada siswa (student centered) karena siswa akan lebih paham terhadap materi ketika mereka dilibatkan langsung pada pembelajaran. Model ceramah yang terlalu dominan walau memiliki beberapa dampak positif mengakibatkan contra-produktif efek negative.

Pelaksanaan pembelajaran ekonomi akan jauh lebih baik jika siswa dihadapkan pada masalah ekonomi yang mereka rasakan dalam kehidupan sehari-hari. Siswa sering merasa pelajaran ekonomi adalah sesuatu yang kurang menarik atau kurang menantang untuk dipelajari, karena siswa merasa materi ekonomi terlalu membosankan dan guru hanya selalu 
memberikan materi dengan cara ceramah sehingga siswa menjadi bertambah bosan dan kurang bersemangat. Hal ini yang menyebabkan pemahaman siswa terhadap materi ekonomi sangat rendah dan bingung. Berbeda dengan pembelajaran kontekstual yang berpijak pada pandangan kontruktivisme yang mengarahkan bagaimana cara menghubungkan materi pelajaran ekonomi pada kehidupan sehari-hari.

Untuk meningkatkan motivasi belajar, guru harus inovatif dalam menggunakan cara mengajar yang mampu menciptakan situasi pembelajaran yang menyenangkan dan membangkitkan semangat belajar/ keingintahuan (curiosity). Salah satu model pembelajaran yang mampu membangkitkan intrisnsik motivation dan challenging (menantang) model pembelajaran Project Based Learning (PBL). PBL adalah metode pembelajaran yang menggunakan proyek / kegiatan sebagai media. Peserta didik melakukan eksplorasi, penilaian, interprestasi, sistensis, dan informasi untuk menghasilkan berbagai bentuk hasil belajar. Sebagian guru sudah memahami apa dan bagaimana implementasinya namun pada umumnya sebagian besar guru masih enggan menggunakan model ini karena belum memahami secara detail dan praktis, serta sebagian guru kurang berminat menggunakannya karena mereka menganggap terlalu sulit (complicated).

Motivasi belajar berperan penting bagi siswa dan guru. Pembelajaran mandiri pada pembelajaran yang berasal dari pemikiran dan perilaku yang dihasilkan sendiri oleh siswa yang secara sistematis diarahkan kesasaran pembelajaran mereka. Motivasi intrinsik adalah motivasi dimana perilaku seseorang untuk melakukan atau mencapai sesuatu demi dirinya sendiri. Motivasi intrinsik yang terkandung setiap seseorang berprilaku untuk kepuasan yang melekat dalam perilaku diri sendiri. Sardiman, 2001 : 71) mengemukakan bahwa motivasi belajar adalah keadaan dalam diri seseorang yang mendorongnya untuk melakukan kegiatan untuk mencapai tujuan.

Penelitian sebelumnya banyak penelitian-penelitian yang memengungkap tentang penerapan model pembelajaran Project Based Learning (PBL) untuk meningkatkan motivasi belajar ekonomi. Tetapi keterbaruan dalam penelelitian ini yang menarik dalam penelitian ini adalah penerapan model pembelajaran Project Based Learning (PBL) untuk meningkatkan motivasi belajar ekonomi yang dilakukan dimasa pandemi COVID-19. Penelitian ini bertujuan untuk meningkatkan kemampuan peserta didik dalam pemecahan masalah proyek, memperoleh pengetahuan dan keterampilan baru dalam pembelajaran, membuat peserta didik lebih aktif.

\section{METODE PENELITIAN}

Penelitian ini merupakan penlitian pendekatan kuantitatif dengan metode survey, dengan populasi siswa kelas X Akutansi \& Keuangan Lembaga (AKL) di SMK BINA NUSA 
Bekasi. berjumlah 60 siswa. Jumlah sampel penlitian merunjuk tabel Isaac \& Micheal dengan signifikansi 5\% sebanyak 51 siswa, teknik sampel yang digunakan yaitu teknik random sampling. Pengumpulan data berupa skor di ambil dengan menggunakan penerapan model pembelajaran project based learning selama satu bulan motivasi belajar ekonomi valid dan memiliki reabilitas Alpha dimensi ke I 0,652 dan dimensi ke II sebesar 0,588. Hipotesa penelitian diduga terdapat pengaruh penerapan model pembelajaran project based learing terhadap motivasi belajar siswa. Analisis data penelitian dengan terlebih dahulu mendeskripsikan, selanjutnya dilakukan uji prasyarat menguji normalitas dan mohogenitas data, setelah didapatkan data yang normal dan homogeny dilanjutkan dengan uji hipotesis dengan analisis regresi sederhana.

\section{HASIL PENELITIAN}

Hasil setelah didapat data penelitian selanjutnya data penelitian dideskripsikan sebagai berikut : Variabel 1 Model Pembelajaran Project Based Learning jumlah responden sebanyak 51 siswa dengan skor terendah 50 dan skor tertinggi 54, dengan rata-rata skor (mean) sebesar 74,86, rentang skor 45, simpangan baku atau standard devisi 10,878, modus 70, median 73,00. Variabel 2 Motivasi Belajar Ekonomi jumlah sampel atau responden sebanyak 51 siswa dengan skor terendah 95 dan skor tertinggi 99, dengan rata-rata skor (mean) 74,73, rentang skor 45, simpangan baku atau standard devisi 12,584, skor modus 61, median 73,00.

Tabel 1.

Deskripsi Data Variabel Penelitian

\begin{tabular}{|c|c|c|c|}
\hline & & $\begin{array}{c}\text { Project Based } \\
\text { Learning } \\
\end{array}$ & $\begin{array}{c}\text { Motivasi Belajar } \\
\text { Ekonomi }\end{array}$ \\
\hline \multirow{2}{*}{$\mathrm{N}$} & Valid & 51 & 51 \\
\hline & Missing & 0 & 0 \\
\hline \multirow{2}{*}{\multicolumn{2}{|c|}{ Mean }} & 74.8 & 74.7 \\
\hline & & 6 & 3 \\
\hline \multirow{2}{*}{\multicolumn{2}{|c|}{ Std. Error of Mean }} & 1.52 & 1.76 \\
\hline & & 3 & 2 \\
\hline \multirow{2}{*}{\multicolumn{2}{|c|}{ Median }} & 73.0 & 73.0 \\
\hline & & 0 & 0 \\
\hline \multicolumn{2}{|c|}{ Mode } & 70 & $61^{\mathrm{a}}$ \\
\hline \multirow{2}{*}{\multicolumn{2}{|c|}{ Std. Deviation }} & 10.8 & 12.5 \\
\hline & & 78 & 84 \\
\hline \multirow{2}{*}{\multicolumn{2}{|c|}{ Variance }} & 118. & 158. \\
\hline & & 321 & 363 \\
\hline \multicolumn{2}{|c|}{ Range } & 45 & 45 \\
\hline \multicolumn{2}{|c|}{ Minimum } & 50 & 54 \\
\hline
\end{tabular}




\begin{tabular}{lrr}
\hline Maximum & 95 & 99 \\
\hline \multirow{2}{*}{ Sum } & 381 & 381 \\
& 8 & 1 \\
\hline
\end{tabular}

\section{Uji Normalitas}

Data penelitian yang telah dideskripsikan selanjutnya dilakukan uji prasyarat analisis data menggunakan program SPSS versi 20. Yaitu dengan menguji normalitas dan homogenitas data. Uji normalitas data dengan menggunakan uji Kolmogorov-SmimovZ Variabel 1 Model Pembelajaran Project Based Learning diperoleh nilai 716 , angka ini sama dengan hasil secara manual dan nilai Asymp.Sig (2-tailed) sebesar 0,685 atau dapat ditulis sebagai nilai probalitas (p-value) 0,685 > 0,05 atau Ho diterima, dengan demikian data Model Pembelajaran Project Based Learning berdistribusi Normal. Variabel 2 Motivasi Belajar Ekonomi di peroleh nilai Kolmogorov-SmimovZ 833, angka ini sama dengan hasil secara manual dan nilai Asymp.Sig (2-tailed) sebesar 491, atau dapat ditulis sebagai nilai probalitas (p-value) 0,491 > 0,05 atau Ho diterima, dengan demikian data otivasi Belajar Ekonomi berdistribusi Normal.

\section{Tabel 2.}

Normalitas

One-Sample Kolmogorov-Smirnov Test

\begin{tabular}{|c|c|c|c|}
\hline & & $\begin{array}{c}\text { Project } \\
\text { Based } \\
\text { Learning }\end{array}$ & $\begin{array}{c}\text { Motivasi Belajar } \\
\text { Ekonomi }\end{array}$ \\
\hline $\mathrm{N}$ & & 51 & 51 \\
\hline \multirow{2}{*}{$\begin{array}{l}\text { Normal } \\
\text { Parameters }{ }^{\mathrm{a}, \mathrm{b}}\end{array}$} & Mean & 74.86 & 74.73 \\
\hline & $\begin{array}{l}\text { Std. } \\
\text { Deviation }\end{array}$ & 10.878 & 12.584 \\
\hline \multirow{3}{*}{$\begin{array}{l}\text { Most Extreme } \\
\text { Differences }\end{array}$} & Absolute & .100 & .117 \\
\hline & 'ositive & .100 & .117 \\
\hline & Negative & -.064 & -.090 \\
\hline \multicolumn{2}{|c|}{ Kolmogorov-Smirnov Z } & .716 & .833 \\
\hline \multicolumn{2}{|c|}{ Asymp. Sig. (2-tailed) } & .685 & .491 \\
\hline
\end{tabular}

\section{Uji Homogenitas}

Uji Homogenitas dilakukan dengan maksud untuk mengetahui apakah sebaran data dari setiap variable tidak menyimpang dari ciri-ciri data yang mohogen pengujian homogenitas dilakukan terhadap varian regresi dependen atau variable-variabel independen dengan menggunakan statistik 
Tabel 3.

Uji Homogenitas

Test of Homogeneity of Variances

\begin{tabular}{cccc}
\hline Skor & & & \\
\hline Levene Statistic & df1 & df2 & Sig. \\
\hline 3.0 & 1 & 100 & .085 \\
26 & & &
\end{tabular}

Dari hasil analisis pada tabel Test of Homogeneity of Variances Leave Statistic 3,026 ; df1 = $1 ;$ df2 $=100$, dan p-value $=0,085>0,05$ atau Ho diterima. Dengan demikian kedua kelompok data berasal dari kelompok yang homogen.

\section{Uji Hipotesis}

Tabel 4.

Uji Hipotesis Coefficients ${ }^{a}$

\begin{tabular}{|c|c|c|c|c|c|c|}
\hline \multicolumn{2}{|c|}{ Model } & \multicolumn{2}{|c|}{$\begin{array}{c}\text { Unstandardized } \\
\text { Coefficients }\end{array}$} & \multirow{2}{*}{$\begin{array}{c}\text { Standardized } \\
\text { Coefficients } \\
\text { Beta } \\
\end{array}$} & \multirow[t]{2}{*}{$\mathrm{t}$} & \multirow[t]{2}{*}{ Sig. } \\
\hline & & $\mathrm{B}$ & Std. Error & & & \\
\hline \multirow[b]{2}{*}{1} & (Constant) & 47.278 & 11.856 & & 3.988 & .000 \\
\hline & $\begin{array}{l}\text { Project Based } \\
\text { Learning }\end{array}$ & .367 & .157 & .317 & 2.339 & .023 \\
\hline
\end{tabular}

a. Dependent Variable: Skor

Hasil uji hipotesis dengan menggunakan SPSS 20 sebagai berikut :

1. Persamaan Regresi Linear

Diperoleh dari kolom B, sehingga persamaan regresi : Y $=47,278+0,367$ X. Dari hasil analisis diperoleh $t_{\text {hit }}=2,339$ dan $p$-value $=0,23>0,05$ atau Ho diterima. Dengan demikian Model Pembelajaran Project Based learning berpengaruh positif terhadap Motivasi Belajar Ekonomi Siswa. 
Tabel 5.

Uji Linearitas dan Signifikansi Persamaan Regresi

ANOVA Table

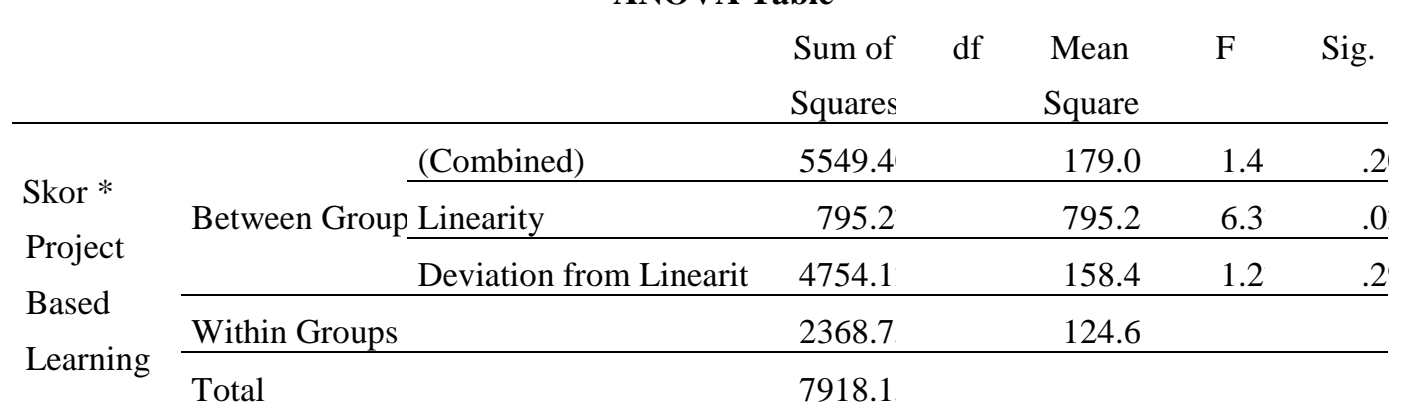

2. Uji Linearitas dan Signifikansi Persamaan Regresi

Pengujian linearitas dan signifikansi persamaan regresi ditentukan berdasarkan ANOVA table dan ANOVAa, sebagai berikut :

Hipotesis statistic :

Ho : $\mathrm{Y}=\mathrm{a}+\mathrm{Bx}$ (regresi linear)

Ho : $\mathrm{Y}=\mathrm{a}+\mathrm{Bx}$ (Regresi tak linear)

Uji linearitas persamaan garis regresi diperoleh baris Deviantion from Linearity, yaitu $F_{h i t}$ $(\mathrm{TC})=1,271$ dan $\mathrm{p}$-value 0,296 > 0,05. Hal ini berarti Ho diterima atau persamaan regresi $\mathrm{Y}$ atas $\mathrm{X}$ adalah linear atau berupa garis linear.

Tabel 6.

Uji Signifikansi ANOVA ${ }^{a}$

\begin{tabular}{|c|c|c|c|c|c|c|}
\hline Model & & Sum of Squares & df & Mean Square & $\mathrm{F}$ & Sig. \\
\hline \multirow{3}{*}{1} & Regression & 795.279 & 1 & 795.279 & 5.471 & $.023^{\mathrm{b}}$ \\
\hline & Residual & 7122.878 & 49 & 145.365 & & \\
\hline & Total & 7918.157 & 50 & & & \\
\hline
\end{tabular}

Hipotesis statistik :

Ho : b 0 (regresi tak bearti)

Hi : b 0 (regresi bearti)

Uji signifikansi persamaan garis regresi diperoleh dari baris regression kolom ke-5, yaitu $\mathrm{F}$ hit $(\mathrm{b} / \mathrm{a})=5,471$ dan $\mathrm{p}$-value $=0,023$ atau Ho di terima. Dengan demikian, regresi $\mathrm{Y}$ atau $\mathrm{X}$ adalah signifikan atau Model Pembelajaran Project Based Learning berpengaruh terhadap motivasi belajar ekonomi siswa ini berhipotesis penelitian oleh data empiris. 
Tabel 7.

Uji Signifikansi Koefisien Kolerasi X dan Y

Model Summary

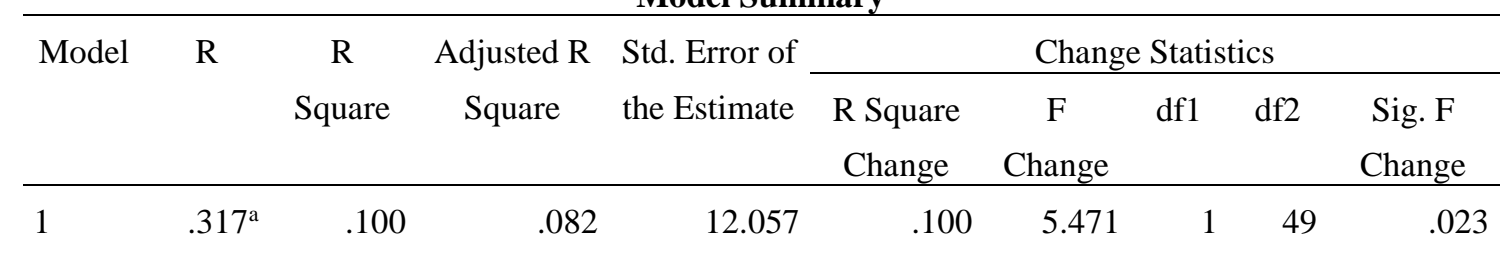

Hipotesis statistik:

$\mathrm{H} 0: \rho=0$

$\mathrm{H} 1: \rho \neq 0$

Uji signifikansi koefisien kolerasi diperoleh dari tabel Model Summary. Terlihat pada baris pertama koefisien kolerasi $\left(r_{x y}\right)=0,317$ dan $F$ hit $\left(F_{\text {change }}\right)=5,471$, dengan $p$-value $=0,023$. Hal ini berarti Ho di terimas. Dengan demikian koefisien kolerasi X dan Y adalah bearti atau signifikan. Dedangkan koefisien determinasi dari tabel di atas terlihat pada baris ke-2 yaitu $\mathrm{R}$ Square = 0,100 yang mengandung makna bahwa 1 variasi variabel motivasi belajar ekonomi.

\section{Pembahasan}

Penerapan model pembelajaran project based learning untuk meningkatkan motivasi belajar siswa kelas X SMK BINA NUSA Bekasi. Dengan demikian hipotesis penelitian ini didukung oleh data empiris. Hasil penelitian ini didukung pendapat Mulyasa (2014: 145) menyatakan bahwa Project Based Learning atau PJBL adalah model pembelajaran yang bertujuan untuk memfokuskan peserta didik pada permasalahan kompleks yang diperlukan dalam melakukan investigasi dan memahami pelajaran melalui investigasi. Model pembelajaran ini bertujuan untuk membimbing peserta didik dalam sebuah proyek kolaboratif yang mengintegrasikan sebagai subyek (materi) kurikulum, memberikan kepada peserta didik untuk menggali konten (materi) dengan menggunakan berbagai cara yang bermanfaat bagi dirinya untuk melakukan eksperimen secara kolaboratif.

Menambahkan pendapat Gora dan Sunarto (2010: 12) juga menyatakan bahwa didalam proses pembelajaran, guru harus melibatkan peserta didik untuk terlihat lebih aktif. Pembelajaran aktif adalah pembelajaran yang memberikan kesempatan kepada para siswa untuk berperan lebih aktif dalam proses pembelajaran mencari informasi, mengolah informasi dan menyimpulkan kemudian untuk diterapkan atau dipraktikkan dengan menyediakan lingkungan belajar yang membuat siswa tidak tertekan dan senang melakukan 
kegiatan belajar.

\section{SIMPULAN}

Dari hasil penelitian dan pembahasan dapat disimpulkan bahwa penerapan model pembelajarn projrct based learning berpengaruh terhadap meningkatkan motivasi belajar siswa kelas $\mathrm{X}$. Regresi $\mathrm{Y}$ atau $\mathrm{X}$ adalah signifikan, koefisien kolerasi pada ke-2 yaitu $\mathrm{R}$ Square $=0,100$ yang mengandung makna bahwa $100 \%$.

\section{REFERENCES}

Curtis, D. 2011. Project-Based Learning: Real-World Issues Motivate Students: Concrete, authentic project-based learning helps students illustrate core knowledge. (Online), http://www. edutopia.org, diakses 2 agustus 2011.

Dahlan, Ahmad. “Model Project Based Learning”, Blog Ahmad Dahlan.

http://www.eurekapendidikan.com/2014/12/model-project-based learninglandasan.html (13 September 2015)

Global SchoolNet.( 2000). Introduction to Networked Project-Based Learning.Diambil dari http://www.gsn.org/web/pbl/whatis.htm

Rezeki, Rina Dewi., dkk. 2015. Penerapan Metode Pembelajaran Project Based Learning (PjBl) Disertai dengan Peta Konsep Untuk meningkatkan Prestasi dan Aktivitas Belajar Siswa Pada Materi Redoks Kelas x-3 SMA Negeri Kebakkramat Tahun pelajaran 2013/2014. Jurnal Pendidikan Kimia(JPK), Vol. 4 No.1: 74-81.

Lestari, Tutik. 2015. Peningkatan Hasil Belajar Kompetensi Dasar menyajikan ContohContoh Ilustrasi Dengan Model Pembelajaran Project Based Learning dan Metode Pembelajaran Demonstrasi Bagi Siswa Kelas XI Multimedia SMK Muhammadiyah Wonosari. Skripsi. Program Studi Pendidikan Teknik Informatika Fakultas Teknik Universitas Negeri Yogyakarta. Yogyakarta.

Curtis, D. 2011. Project-Based Learning: Real-World Issues Motivate Students: Concrete, authentic project-based learning helps students illustrate core knowledge. (Online), http://www. edutopia.org. diakses 2 agustus 2011.

Kamdi, W. 2007. Pembelajaran Berbasis Proyek: Model Potensial untuk Peningkatan Mutu Pembelajaran. (Online), http://waras khamdi.com/ pembelajaran-berbasis-proyek/ html. diakses 8 Agustus 2011.

Colley, K. 2008. Project Based Science Instruction: A Primer An Introduction and Learning Cycle for Project Based Science. Jurnal The Science Teacher, Vol 75:23-28.

Krajcik, J.S., Harold, S., dan Morten, F.V.L. 2008. How Do Geckos. Using Phenomena to 
Frame Project-Based Science in Chemistry Class. Jurnal The Science Teacher, Vol 75:38-49.

Sardiman. (2011). Interaksi dan Motivasi Belajar-Mengajar. Jakarta: PT Raja Grafindo Persada, 2007.

Taufik, M. (2014). Pengaruh Pendekatan Open Ended terhadap Motivasi Belajar dan Kemampuan Pemecahan Masalah Matematis Siswa SMAN 5 Mataram. AgriSains, 5(1), 58-86.

Nurohman, Sabar. "Pendekatan Project Based Learning sebagai Upaya Internalisasi Scientific Method bagi Mahasiswa Calon Guru Fisika”. http://staff.uny.ac.id/sites/default/files/132309687/pro ject-based-learning.pdf. Januari 2014). 